\title{
PRESOWING TREATMENT OF SEEDS OF SPRING WHEAT WITH LOW-FREQUENCY ELECTROMAGNETIC FIELD
}

\section{N.S. LEVINA ${ }^{1}$, Yu.V. TERTYSHNAYA ${ }^{1,}$, I.A. BIDEY1, O.V. ELIZAROVA', L.S. SHIBRYAEVA 1,2}

\author{
${ }^{1}$ Federal Scientific Agroengineering Center VIM, 5, 1-i Institutskii proezd, Moscow, 109428 Russia, e-mail lev- \\ ina vim@mail.ru; \\ ${ }^{2}$ N.M. Emanuel Institute of Biochemical Physics RAS, Federal Agency of Scientific Organizations, 4, ul. Kosygina, \\ Moscow, 119334 Russia, e-mail terj@rambler.ru \\ ORCID: Levina N.S. orcid.org/0000-0003-2922-2670 \\ The authors declare no conflict of interests
}

Received August 3, 2016

\section{Abstract}

Seeking for effective natural stimulants that enhance crop productivity is relevant to ensure high quality yield production. The influence of physical factors (e.g. electric and magnetic fields, ultraviolet, infrared, laser irradiation) on seeds which contributes to an increase in sowing properties, plant photosynthetic activity, survival and yield is in the focus for researchers. However, a more detailed study of the mechanism of energy influence on the internal seed structure, plant growth and development sill remained relevant. Besides, it is necessary to develop effective, simple, reliable and low cost devices for agrophysical stimulation. The Federal Scientific Agroengineering Center VIM together with the Kazakh National Agrarian University has developed low frequency electromagnetic radiation construct which is mounted directly on combine-harvester to expose seeds to electromagnetic field during harvesting. The purpose of this study is to assess the sowing qualities of seeds and biometric indicators of the derived plants of spring wheat (Triticum aestivum L.) variety Omskaya 18, as influenced by low frequency electromagnetic fields depending on intensity and time of irradiation. The seeds were harvested in September 2015 (Republic of Kazakhstan). The construct used was developed on the basis of the magnetotherapy apparatus Almag-02, placed on a combine-harvester Enisey 1200 NM (Russia). We compared different modes of seed exposure. These were flow treatment (a dynamic mode) at magnetic induction $\mathrm{B}=6 \mathrm{mT}$ and frequency $\mathrm{f}=10 \mathrm{~Hz}$; static treatment for 3,6 , and $9 \mathrm{~min}$ at $6 \mathrm{mT}$ and $3 \mathrm{~Hz} / 16 \mathrm{~Hz}$, and flow treatment at $6 \mathrm{mT}$ and $3 \mathrm{~Hz} / 16 \mathrm{~Hz}$. Irradiated and non-irradiated seeds (control) were used in further studies. Seed germination parameters were estimated in laboratory tests. The seeds were germinated on filter paper in Petri dishes in darkness in a thermostat LP-113 (Labor Muszeripari Muvek Esztergom, Hungary). To assess the growth and development of seedlings and plants we used a phytotron Vic-Terra (FSAC VIM, Russia). Treatment with low frequency electromagnetic field for 9 min in static mode increased seed germination energy and germination rate by $12-13 \%$. When irradiating seed flow, germination was below the control, e.g. at $6 \mathrm{mT}, 10 \mathrm{~Hz}$ this parameter decreased by $4.3 \%$ in the laboratory test and by $3.5 \%$ in the phytotron. Plant weight and height were higher in the irradiated samples. Under static irradiation for $9 \mathrm{~min}$ at $6 \mathrm{mT}, 3 \mathrm{~Hz}$ and $16 \mathrm{~Hz}$ the plant weight was 0.56 and $0.59 \mathrm{~g}$, respectively. The smallest weight $(0.46 \mathrm{~g}$ per plant) resulted from flow treatment at $6 \mathrm{mT}, 16 \mathrm{~Hz}$. After storage of treated seeds at laboratory conditions for 3 and 7 months the indicators (germination energy and germination rate) remained satisfactory. The best result was noted for seeds, processed in static mode for $9 \mathrm{~min}$ at $6 \mathrm{mT}, 3 \mathrm{~Hz} / 16 \mathrm{~Hz}$. A decline in sowing properties did not exceed $6 \%$, indicating the preserving effect of the electromagnetic field.

Keywords: wheat, Triticum aestivum, seeds, low-frequency electromagnetic field, germination rate, germination energy, phytotron

Seed accumulate genetic and biological potentials of a plant variety and determine considerably the quantity and quality of the yield that defines the role of seed production in the sustainable plant growing as a whole [1-3]. Germination of seeds when their nutrients undergo significant qualitative changes is one of the critical periods of ontogenesis affecting all the growth and development stages. These are seeds where physicochemical and physicobiological processes as 
well as morphological modifications leading to increased permeability of coverings occur, the activity of hydrolytic and oxidation-reduction enzymes rises, the cell division speeds up, and reactions maintaining normal germ functions are activated [4].

The bioenergy potential of seeds when stored is depleted that may have adverse effects on the growth, development and disease-resistance of the resulting plants. To restore the potential, various pre-sowing seed treatment methods are applied which improve seed properties and increase plant yields [5-7].

In recent years, electrophysical treatment methods for plants and seeds of grain, vegetable and legume crops have been introduced extensively into agricultural practices to intensify plant growing [8, 9]. Physical factors influencing seeds may include electromagnetic fields of various ranges (from $\gamma$-radiation to UHF radio-frequency range), X-ray radiation, ultraviolet and optical radiation (particularly, laser red radiation with $\lambda=632.8 \mathrm{~nm}$ ), infrared radiation, electric corona field, and ultrasonic exposure $[10,11]$.

There are about 170 published works where results of using different seed irradiation sources are reflected [8]. Also, there are studies in which the mild exposure of physical factors stimulated the crop yield and improved the quality of products [12, 13]. For example, the laser treatment increased electrical conductivity of plant tissues by 10-14\%, improved ion-exchange processes, enhanced permeability of biological membranes, water adsorption, spare capacities and protective reactions of seeds. The leaf surface area, stooling and diseaseresistance of plants increased [8].

Using the electromagnetic exposure of different frequencies may result in yield gain by $10-12 \%$, kill a seed infection, increase germination energy and germinating ability of seeds [14-16], enhance plant resistance to fungal and bacterial diseases [17, 18]. The research paper of I.V. Egorova et al. [19] contains data that the high-frequency electromagnetic field treatment (UHF EMF) enhances the biological value of wheat grains due to an increase in some water-soluble vitamin contents, and influences biometric indicators of radicles. A good number of experimental works are dedicated to the UV irradiation of seed materials [20-23]. It has been noted that plants are highly sensitive to irradiation conditions $[24,25]$. So, growth processes are inhibited in the short-wave region $(\lambda=254 \mathrm{~nm})$, while in the mid-wave $(\lambda=313 \mathrm{~nm})$ and long-wave regions $(\lambda=365 \mathrm{~nm})$ they are stimulated.

In studies of grain, vegetable and forage crops, it was found that the short-term exposure to high-voltage corona discharge resulted in accelerating seed germination both in the laboratory and field conditions. The germination energy increases by 5-22\%, there is a higher number of plants survived until crops. It has been noted that, on day 5-7 of their germination, plants derived from the treated seeds outgrow those from untreated seeds, and such outgrowing persists throughout the vegetation period. It is generally believed that, during such treatment, the germination energy and increase in the field germination rate of seeds are positively influenced by their surface disinfection [26] which restricts the spread and development of powdery mildew, brown rust, root rots and other diseases.

In this work, we have shown for the first time that the static lowfrequency electromagnetic irradiation of spring wheat seeds (Triticum aestivum L.) during the combine harvesting improves sowing properties and biometric indicators of plants as well as increases the seed quality stored for 7 months (under laboratory conditions). In the dynamic irradiation mode, sowing qualities of seeds and morphological parameters of plants were somewhat worse.

Our purpose was to assess the impact of the low-frequency electromag- 
netic field of various intensity and time of irradiation on the germination energy, germinating ability of spring wheat seeds and biometric indicators of spring wheat plants while growing and developing under the phytotron conditions.

Technique. During combine harvesting, seeds of spring wheat (Triticum aestivum L.) variety Omskaya 18 (Ulanskaya MTS, Republic of Kazakhstan, September 2015) were exposed to the low-frequency electromagnetic field using radiators of Almag-02 magnetotherapy device (Yelatma Instrument-Making Enterprise, Russia) installed on Enisei 1200 NM combine-harvester (Krasnoyarsk Combine Harvester Plant, Russia).

The system allowed irradiation of both moving flow and stationary mass of seeds varying the electromagnetic field exposure time and characteristics. The following programs of the magnetotherapy device were used: flow treatment of seeds (dynamic mode) at the magnetic induction $\mathrm{B}=6 \mathrm{mT}$ and frequency $\mathrm{f}=10$ $\mathrm{Hz}$ (Program № 7); static treatment for 3; 6; $9 \mathrm{~min}$ at $\mathrm{B}=6 \mathrm{mT}$ and $\mathrm{f}=3 \mathrm{~Hz}$ or $\mathrm{f}=16 \mathrm{~Hz}$ (Programs № 22 or № 23, respectively); flow treatment in Programs № 22 and № 23. Flow irradiated seeds were sampled from beneath the top of the elevator that delivers the seeds from a grain screw conveyor to a tank. During the static treatment mode, samples taken from the non-irradiated thrashed heap in a tank were spread in a thin layer on a fixed surface and radiators were placed on them.

Irradiated and non-irradiated seeds sampled from the tank (control samples) were stored under laboratory conditions and used in studies. In 3 and 7 months, germination energy and germinating ability of the seeds were identified in accordance with State Standard GOST 12038-84 [27). The seeds were germinated on a filter paper in Petri dishes under darkroom conditions in LP-113 thermostat (Labor Muszeripari Muvek Esztergom, Hungary) (in 4 replicates). Each sample contained 100 seeds. The germination energy was identified on day 4 , the germinating ability - on day 7-8.

The formation of seedlings, growth and development of plants were studied on a real-time basis in Vic-Terra vegetation and growth chamber (phytotron with the overall dimensions of $3100 \times 1700 \times 1400 \mathrm{~mm}$ ) (FSAC VIM, Russia) under controlled conditions [28]. Twelve containers $(850 \times 1300 \mathrm{~mm})$ were placed in the isolated box of the phytotron. The unit was complete with lighting, computer-based air temperature and relative humidity control as well as irrigation systems. The seeds were sowed in 12 containers filled with soil ( $\mathrm{pH} \mathrm{6.7-7.0)} \mathrm{on}$ December 4, 2015. The depth of seeding was 3-4 cm. There were two furrows spaced $15 \mathrm{~cm}$ in each container. Biometric indicators of the plants (shoot weight and height, root length) were identified in 31 days.

The experimental findings are represented as the arithmetic mean $(X)$ and its standard error $( \pm x)$. They were calculated using Statistica 8.0 (Dell Software Inc., USA) and Microsoft Excel 2007.

Results. The static low-frequency electromagnetic irradiation of wheat seeds increased the germination energy and germinating ability by $12.7 \%$ (Fig. 1 , laboratory test). The seeds irradiated in flow in all the programs had lower germination energy and germinating ability as compared to the control samples.

The maximum germinating ability of the seeds in the phytotron $(89-90 \%)$ was observed in the static irradiation for $9 \min (6 \mathrm{mT}, 16 \mathrm{~Hz})$. The earliest seedlings have appeared on day 8 out of the seeds treated in Program № 23 for 6-9 min. Upon exposure, a stem shoot was overgrown with 2 to 5 true green leaves and stopped to grow for a while. At this time, secondary roots and new stem shoots branching the leading shoot were formed. The root system developed, the tillering stage started (Fig. 2). It should be noted that the root system of plants derived from the statically irradiated seeds was more extensive as compared to that 
A

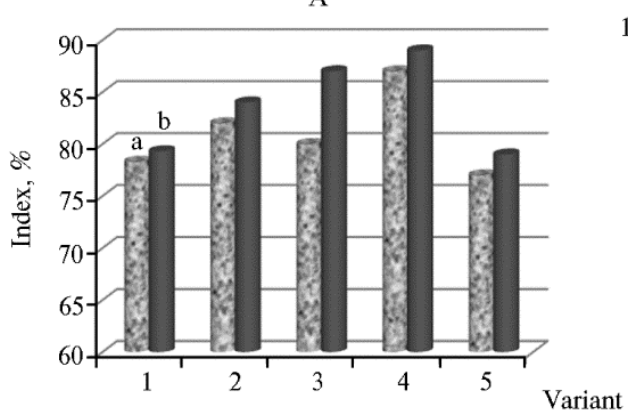

B

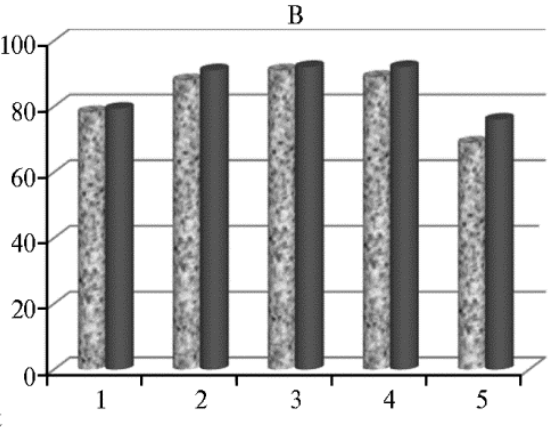

Fig. 1. Germination energy (a) and germinating ability (b) of seeds of spring wheat (Triticum aestivum L.) variety Omskaya 18 exposed to the low-frequency electromagnetic field in the static and flow mode, at the magnetic induction $B=6 \mathrm{mT}$ and frequencies $f=3 \mathrm{~Hz}(\mathrm{~A})$ and $f=16 \mathrm{~Hz}(\mathrm{~B})$ for different time intervals: $1-$ control (untreated); $2-3 \min , 3-6 \min , 4-9 \min$ (static mode); $5-$ flow (laboratory experiment).

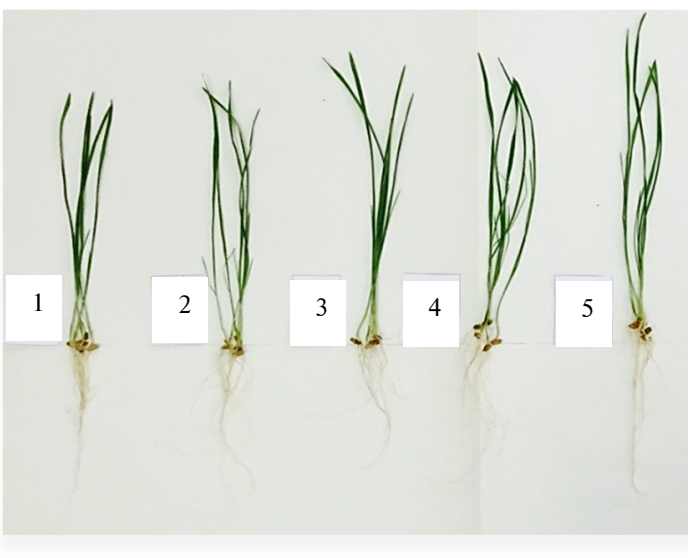

Fig. 2. Spring wheat (Triticum aestivum L.) variety Omskaya 18 plants grown to the initial stage of tillering in the phytotron after seed exposure to the low-frequency electromagnetic field): $1,2,3$ - control (non-irradiated), 4 and 5 - static irradiation at $\mathrm{B}=6 \mathrm{mT}$ and $\mathrm{f}=3$ $\mathrm{Hz}$ for 3 and $9 \mathrm{~min}$, respectively.

The exposure of wheat seeds to the low-frequency magnetic field affected biometric indicators of the plants derived (Table 1). The plant weight changed depending on the impulse frequency and time of irradiation. When using Program № 23, the plants had greater weight, longer roots and were higher. So, the total weight of freshly harvested plants was $0.10-0.15 \mathrm{~g}$ higher than that of the plants derived from the seeds irradiated in Program № 22. In the dynamic flow treatment, there were no significant differences between the two programs. The maximum weights of a plant, i.e. $0.56 \mathrm{~g}$ and $0.59 \mathrm{~g}$, were obtained upon seed irradiation for 9 min in Programs № 22 and № 23, respectively. This was 20-25\% higher than for the control plant. The minimum total weights $(2.30-2.40 \mathrm{~g})$ of plants were observed upon flow treatment of seeds in all the programs (see Table 1).

1. Biometric parameters of spring wheat (Triticum aestivum $\mathrm{L}$.) variety Omskaya 18 plants at tillering depending on the mode of low-frequency electromagnetic field irradiation of seeds (laboratory experiment)

\begin{tabular}{|c|c|c|c|c|c|c|c|c|c|c|}
\hline \multirow{3}{*}{ Показатель } & \multirow{3}{*}{$\mathrm{C}$} & \multicolumn{4}{|c|}{ P № 22} & \multirow{2}{*}{\multicolumn{4}{|c|}{$\begin{array}{l}\text { P № } 23 \\
\text { time, } \min \end{array}$}} & \multirow{3}{*}{ P № 7 (f) } \\
\hline & & \multicolumn{4}{|c|}{ irradiation time, $\min$} & & & & & \\
\hline & & $3(\mathrm{~s})$ & $6(\mathrm{~s})$ & $9(\mathrm{~s})$ & (f) & $3(\mathrm{~s})$ & $6(s)$ & $9(\mathrm{~s})$ & (f) & \\
\hline Total weight of plants, $g$ & 2.35 & 2.55 & 2.50 & 2.80 & 2.50 & 2.60 & 2.60 & 2.95 & 2.30 & 2.40 \\
\hline$\Delta, \%$ & & 0.25 & 0.15 & 0.45 & 0.15 & 0.25 & 0.25 & 0.60 & 0.05 & 0.05 \\
\hline Weight of a plant, $g$ & 0.47 & 0.51 & 0.50 & 0.56 & 0.50 & 0.52 & 0.52 & 0.59 & 0.46 & 0.48 \\
\hline$\Delta, \%$ & & 0.04 & 0.03 & 0.09 & 0.03 & 0.05 & 0.05 & 0.12 & -0.01 & 0.01 \\
\hline Root length, cm & 2.12 & 2.24 & 3.28 & 2.50 & 3.70 & 3.90 & 3.00 & 4.90 & 3.80 & 3.30 \\
\hline$\Delta, \%$ & & 0.12 & 1.16 & 0.36 & 1.58 & 1.78 & 0.88 & 2.78 & 1.68 & 1.18 \\
\hline Plant height, $\mathrm{cm}$ & 29.0 & 30.2 & 36.6 & 38.5 & 38.0 & 34.7 & 35.0 & 36.4 & 30.2 & 32.7 \\
\hline$\Delta, \%$ & & 1.2 & 7.6 & 9.5 & 9.0 & 5.7 & 6.0 & 7.4 & 1.2 & 3.7 \\
\hline
\end{tabular}

$\mathrm{N}$ o t e. $\mathrm{C}$ - control, $\mathrm{P}$ - irradiation program (see the program description in the Technique section); $\Delta, \%-$ difference between indicators of plants derived from the irradiated and non-irradiated seeds; $\mathrm{f}-$ flow irradiation, $\mathrm{s}-$ static mode. The relative error of the mean values did not exceed $5 \%$. 
It was important to know whether the stimulating effect of the electromagnetic field was preserved when storing seeds under laboratory conditions. It was found out that the exposure of seeds to the low-frequency magnetic field was good for their quality after storage (Table 2).

2. Germination energy and germinating ability of seeds in spring wheat (Triticum aestivum L.) variety Omskaya 18 after storage depending on the mode of lowfrequency electromagnetic field irradiation ( $X \pm x$, laboratory experiment)

\begin{tabular}{|c|c|c|c|c|c|c|c|c|c|c|}
\hline \multirow{3}{*}{ Parameter } & \multirow{3}{*}{$\mathrm{C}$} & \multicolumn{4}{|c|}{ P № 22} & \multicolumn{4}{|c|}{ P № 23} & \multirow{3}{*}{$\begin{array}{l}\text { P № } 7 \\
\text { (f) }\end{array}$} \\
\hline & & \multicolumn{8}{|c|}{ irradiation time, $\min$} & \\
\hline & & $3(\mathrm{~s})$ & $6(\mathrm{~s})$ & $9(\mathrm{~s})$ & (f) & $3(s)$ & $6(\mathrm{~s})$ & $9(\mathrm{~s})$ & (f) & \\
\hline \multirow{2}{*}{\multicolumn{11}{|c|}{ Upon storage for $3 \mathrm{months}$}} \\
\hline \multirow{2}{*}{\multicolumn{2}{|c|}{$\begin{array}{l}\text { Germination energy } \\
\text { (December 2, 2015), }\end{array}$}} & & & & & & & & & \\
\hline & $783+12$ & $820+0.9$ & $800+11$ & $870+0.8$ & $770+12$ & $880+12$ & $910+0.8$ & $890+0.9$ & $690+13$ & $740+14$ \\
\hline$\Delta, \%$ & & 3.7 & 1.7 & 8.7 & -1.3 & 9.7 & 12.7 & 10.7 & -9.3 & -4.3 \\
\hline \multicolumn{11}{|l|}{ Germinating ability } \\
\hline 2015$), \%$ & $79.3 \pm 1.2$ & $84.0 \pm 0.8$ & $87.0 \pm 0.9$ & $89.0 \pm 1.1$ & $79.0 \pm 1.3$ & $91.0 \pm 0.9$ & $92.0 \pm 1.2$ & $92.0 \pm 0.9$ & $76.0 \pm 1.5$ & $75.0 \pm 1.3$ \\
\hline \multirow[t]{2}{*}{$\Delta, \%$} & & 4.7 & 7.7 & 9.7 & -0.3 & 11.7 & 12.7 & 12.7 & -3.3 & -4.3 \\
\hline & & & J p o n s & torage & for $7 \mathrm{r}$ & months & & & & \\
\hline \multicolumn{11}{|l|}{ Germination energy } \\
\hline $\begin{array}{l}\text { (April 15, 2016), \% } \\
\Delta, \%\end{array}$ & $75.7 \pm$ & $\begin{array}{c}80.0 \pm 0.9 \\
4.3\end{array}$ & $\begin{array}{c}81.0 \pm 0.9 \\
5.3\end{array}$ & $\begin{array}{c}85.0 \pm 1.2 \\
9.3\end{array}$ & $\begin{array}{l}61.0 \pm 2.0 \\
-14.7\end{array}$ & $\begin{array}{c}83.0 \pm 1.3 \\
7.3\end{array}$ & $\begin{array}{c}83.0 \pm 1.2 \\
7.3\end{array}$ & $\begin{array}{c}86.0 \pm 0.9 \\
10.3\end{array}$ & $\begin{array}{c}68.0 \pm 1.1 \\
-6.7\end{array}$ & $\begin{array}{l}5.0 \pm 1.6 \\
-0.7\end{array}$ \\
\hline \multicolumn{11}{|l|}{ Germinating ability } \\
\hline 2016$), \%$ & $77.7 \pm 1.3$ & $84.0 \pm 1.2$ & $85.0 \pm 0.9$ & $88.0 \pm 1.1$ & $66.0 \pm 1.4$ & $86.0 \pm 0.9$ & $86.0 \pm 0.8$ & $89.0 \pm 1.2$ & $69.0 \pm 1.4$ & $76.0 \pm 1.3$ \\
\hline$\Delta, \%$ & & 6.3 & 7.3 & 10.3 & -11.7 & 8.3 & 8.3 & 11.3 & -8.7 & -1.7 \\
\hline $\begin{array}{l}\mathrm{Note} \text {. C - } \\
\text { difference betv }\end{array}$ & indic & $\begin{array}{l}\text { radiati } \\
\text { of pla }\end{array}$ & $\begin{array}{l}\text { progra } \\
\text { deriv }\end{array}$ & $\begin{array}{l}\text { (see th } \\
\text { from } t\end{array}$ & program & descriptiol & $\begin{array}{l}n \text { in the } \\
\text { n-irradi }\end{array}$ & Technique & $\begin{array}{l}\text { esection) } \\
; \mathrm{f}-\text { flo }\end{array}$ & $\Delta, \%-$ \\
\hline
\end{tabular}

The maximum increase of the seed germinating ability as compared to the control samples (by $12.7 \%$ ) was observed after 3 months of storage for the seeds treated in Program № $23(6 \mathrm{mT}, 16 \mathrm{~Hz}, 6$ and $9 \mathrm{~min})$. There was some decline in sowing qualities of seeds in 7 months of storage as compared to those after 3 months (see Table 2). For example, the difference of both germination energy and germinating ability in the static treatment of seeds in Program № 22 (3-9 min) did not exceed $2.0 \%$. The germinating ability of the seeds treated in Program № 23 decreased by 3-6 \%. It should be noted that the indicators were significantly lower for the seeds exposed to the electromagnetic field in the flow in Programs № 22 and № 23.

Thus, the exposure of wheat seeds to the low-frequency electromagnetic field during harvesting contributes to the increase in their germination energy, germinating ability, and, thereafter, in the weight, root length and height of the plants derived. The electromagnetic exposure effectiveness depends on the impulse frequency and time of irradiation of seeds. In our experiments, the maximum stimulating effect on the sowing qualities of seeds and biometric indicators of plants was observed in the treatment for $9 \mathrm{~min}$ at the electromagnetic induction of $6 \mathrm{mT}$ and the frequency of $16 \mathrm{~Hz}$. The seed germination energy and germinating ability have increased by $12-13 \%$, and the plant weight at the tillering stage has increased by $20-25 \%$ as compared to the control samples (nonirradiated seeds). When treating the seed flow, the germinating ability of the seeds in the laboratory conditions decreased. It was found out that the magnetic field had positive impact on the seed properties after 3 and 7 months of storage under laboratory conditions.

\section{REFERENCES}

1. Buchachenko A.L., Kouznetsov D.A., Arkhangelsky S.E., Orlova M.A., $\mathrm{M}$ a r k a ri a n A.A. Spin biochemistry: magnetic ${ }^{24} \mathrm{Mg}-{ }^{25} \mathrm{Mg}-{ }^{26} \mathrm{Mg}$ isotope effect in mitochondrial 
ADP phosphorylation. Cell Bichem. Biophys., 2005, 43: 243-251 (doi: 10.1385/CBB:43:2:243).

2. Yakushev V.P., Mikhailenko I.M., Dragavtsev V.A. Reserves of agrotechnologies and breeding for cereal yield increasing in the russian federation. Agricultural Biology, 2015, 50(5): 550-560 (doi: 10.15389/agrobiology.2015.5.550eng).

3. D e m mig-A a m s B., A d a $\mathrm{m} \mathrm{W}$. Photoprotection in an ecological context: the remarkable complexity of thermal energy dissipation. New Phytol., 2006, 172: 11-21 (doi: 10.1111/j.1469-8137.2006.01835.x).

4. Kreslavski V.D., Carpentier R., Klimov V.V., Allakhverdiev S.I. Transduction mechanisms of photoreceptor signals in plant cells (Review). Journal of Photochemistry and Photobiology C: Photochemistry Reviews, 2009, 10: 63-80 (doi: 10.1016/j.jphotochemrev.2009.04.001).

5. Shi Q., Ni e S.Q., Hu n g L.Q. New progression of chemical component and pharmacological studies of radix bupleuri. Chinese Journal of Experimental Traditional Medical Formulae, 2002, 8: 53-56.

6. Hirota N., Nakagawa J., Ko i c hi K. Effects of a magnetic field on the germination of plants. J. Appl. Phys., 1999, 85: 5717-5719 (doi: 10.1063/1.370262).

7. Yushkova E.I., Pavlovskaya N.E., B otuz N.I. Growth and productivity of potato after treatment of plants by biologically active substance from biohumus. Agricultural Biology, 2013, 3: 73-76 (doi: 10.15389/agrobiology.2013.3.73rus) (in Russ.).

8. Shibryaeva L.S., Sadykov Zh.S., Spolov T.I., Zhalnin E.V., Sadyko $\mathrm{v}$ a S.Zh. Vliyanie vozdeistviya raznykh vidov izluchenii na zernovoi material [Effects of different types of irradiation on seeds]. T.I. Espolova, Zh.S. Sadykova (eds.). Almaty, 2015 (in Russ.).

9. Kreslavski V., Kobzar E., Ivanova E., Kuznetsov E. Effects of short-time red radiation and choline compounds on cytokinin content, chlorophyll accumulation, and photomorphogenesis in wheat seedlings. Plant Growth Regul., 2005, 47: 9-15 (doi: 10.1007/s10725005-0861-6).

10. Mu ne e r S., Ki m E.J., Park J.S., Le e J.H. Influence of green, red and blue light emitting diodes on multiprotein complex proteins and photosynthetic activity under different light intensities in lettuce leaves (Lactuca sativa L.). Int. J. Mol. Sci., 2014, 15: 4657-4670 (doi: 10.3390/ijms15034657).

11. Pardo G.P., Agu i 1 a r C.H., M a rtín ez F.R., C a n s e co M.M. Effects of light emitting diode high intensity on growth of lettuce (Lactuca sativa L.) and broccoli (Brassica oleracea L.) seedlings. Annual Research \& Review in Biology, 2014, 19: 2983-2994 (doi: 10.9734/ARRB/2014/10526).

12. M a r k ova S.V., K s e n z N.V. Mekhanizatsiya i elektrifikatsiya sel'skogo khozyaistva, 2000, 5: 30-31 (in Russ.).

13. Rakosy-Tican L., Aurori C.M., Morariu V.V. Influence of near null magnetic field on in vitro growth of potato and wild Solanum species. Bioelectromagnetics, 2005, 26: 548557 (doi: 10.1002/bem.20134).

14. Sahebjamei H., Abdolmaleki P., Ghanati F. Effects of magnetic field on the antioxidant enzyme activities of suspension-cultured tobacco cells. Bioelectromagnetics, 2007, 24: 42-47 (doi: 10.1002/bem.20262).

15. Abdolmaleki P., Ghanati F., Sahebja mei H., S a rvestani A.S. Peroxidase activity, lignification and promotion of cell death in tobacco cells exposed to static magnetic field. Environmentalist, 2007, 27: 435-440 (doi: 10.1007/s10669-007-9080-1).

16. Ali c a m a n glu S., Sen A. Stimulation of growth and some biochemical parameters by magnetic field in wheat (Triticum aestivum L.) tissue cultures. Afr. J. Biotechnol., 2011, 53: 10957-10963 (doi: 10.5897/AJB11.1479).

17. Kondratenko E.P., S oboleva O.M., Egorova I.V., Verbits k y a N.V. Vestnik Krasnoyarskogo gosudarstvennogo agrarnogo universiteta, 2014, 2: 157-162 (in Russ.).

18. E r o k h i n A.I. Zemledelie, 2012, 5: 46-48 (in Russ.).

19. Egorova I.V., Kondrate nk o E.P., S oboleva O.M., Ve rbits k y a N.V. Ratsional'noe pitanie, pishchevye dobavki i biostimulyatory, 2014, 1: 22-23 (in Russ.).

20. F a r r k h A., V a q a r M.A., H a s a n M. Photochemoprevention of ultraviolet B signaling and photocarcinogenesis. Mutation Res., 2005, 571(1-2): 153-173 (doi: 10.1016/j.mrfmmm.2004.07.019).

21. K o vá c s E., K e re s z t e s Á. Effect of gamma and UV-B/C radiation on plant cells. Micron, 2002, 33(2): 199-210 (doi: 10.1016/S0968-4328(01)00012-9).

22. Strat man n J. Ultraviolet-B radiation co-opts defense signaling pathways. Trends Plant Sci., 2003, 8: 526-533 (doi: 10.1016/j.tplants.2003.09.011).

23. St a p let o n A.E., Wa lb ot V. Flavonoids can protect maize DNA from the induction of UV radiation damage. Plant Physiol., 1994, 105: 881-889 (doi: 10.1104/pp.105.3.881).

24. Pfeiffer A., Kunkel T., Hiltbrunner A., Neuhaus G., Wolf I., Speth V., Ad a m E., $\mathrm{N}$ ag y F., S c h a fe $\mathrm{r}$ E. A cell-free system for light-dependent nuclear import of phytochrome. Plant J., 2009, 57: 680-689 (doi: 10.1111/j.1365-313X.2008.03721.x).

25. Tertys h n y a Yu.V., Le vi n a N.S., E 1 i z a rova O.V. Sel'skokhozyaistvennye mashiny $i$ tekhnologii, 2017, 2: 31-36 (doi: 10.22314.2073-7599-2017.2.31-36) (in Russ.). 
26. S i d o r e n k o V.M. Biofizika, 2001, 46(3): 500-504 (in Russ.).

27. GOST 12038-84. Semena sel'skokhozyaistvennykh kul'tur. Metody opredeleniya vskhozhesti [RF State Standard 12038-84. Crop seeds. Estimation of germination rate]. Moscow, 2011 (in Russ.).

28. G ris hi n A.P. Sel'skokhozyaistvennye mashiny i tekhnologii, 2011, 5: 20-23 (in Russ.).

\section{Events}

\section{PLANT GENOME EDITING \& GENOME ENGINEERING}

(3-4 July 2017, Vienna, Austria)

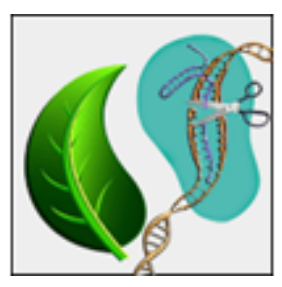

Organization: Vienna International Science Conferences \& Events Association

The International Conference will discuss the advances in genome editing and engineering, notions, challenges, pros and cons, technologies and methods of applications of the genome editing tools like CRISPR/Cas9, TALENs, ZNFs \& AAVs in plants. The case study and sessions will reveal the potential application of Genome editing tools plant biology and crop improvement. Special emphasis on CRISPR system addressing the concept, technology, challenges like off-target effects, efficiency improvement and delivery systems etc.

The research topics:

- $\quad$ Precision genome editing by TALEN, ZFN and others

- CRISPR-CAS9: revolution in genome editing \& engineering

- Current CRISPR-CAS9 technologies and design

- Applications of CRISPR-CAS9 in plants

- Genome editing \& engineering for crop improvement

- Genome editing \& engineering: regulatory aspects

Information: http://viscea.org/plant-genome-editing-genome-engineering/

2ND INTERNATIONAL CONFERENCE ON FOOD CONTAMINANTS (ICFC2017)

(13-14 July 2017, Braga, Portugal)

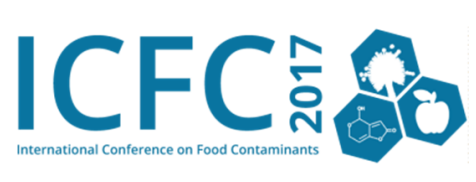

Conference main topics:

Climate change and implications for food safety

Chemical contaminants: occurrence and surveillance

Emerging Chemical Contaminants in Foods Risk Analysis and Food Safety Control Systems

Information: http://www.icfc2017.uminho.pt/index.php/program/conference-topics 